\title{
DIFFERENCES IN SPATIAL STRUCTURE OF AGRICULTURAL AREAS IN KSIEZPOL COMMUNE WITH REGARD TO PRODUCTIVITY OF CROPLAND AND GRASSLAND
}

\author{
Zanna Strek \\ University of Life Sciences in Lublin, Poland \\ zanna.krol@up.lublin.pl
}

\begin{abstract}
Soil quality is one of the most important factors determining the potential for obtaining a high profit from farming. The agricultural quality of soils is described by soil quality classes, and the suitability of soils for growing particular plants or plant communities is described in terms of soil-agricultural complexes. A unified soil classification has been developed for the entire area of Poland, which takes into account the morphological features and physical properties of Polish soils. This classification is a comprehensive descriptive and cartographic study providing rich material in the form of classification maps drawn to the scales of inventory maps. Spatial and economic studies of rural areas often use the method of grouping individual villages by shared features into larger typological classes. This classification was used to develop a land assessment method for the purposes of consolidation and exchange of land. The applicability of this land use classification in economic practice can be enhanced, if the classes are defined by one measure in the form of a productivity index rather than being expressed as a soil quality coefficient. The goal of this paper was to calculate the suitability index for cropland land and grasslands, which could be used to assign villages to similar-suitability groups. The research area encompassed 17 villages of the Księżpol commune, located in the Lubelskie Voivodship, occupying a total area of 1,125.82 ha and divided into 17,513 land parcels (cadastral plots). Data on the surface area occupied by land belonging to the individual land classes were obtained from the county land and buildings register, and the index was calculated on the basis of point values assigned on a 100-point scale. The tests have shown that the application of a single number as the value of productivity for cropland and grassland provides a possibility of grouping respective villages into larger typological units with regard to the similarity of features.
\end{abstract}

Keywords: cropland, grassland, land consolidation, land classification.

\section{Introduction}

In studies concerning spatial and economic phenomena occurring in rural areas, as recounted by [1], respective villages are grouped into larger typological units with respect to similarity of their features. The villages are also grouped with regard to the occurrence of one characteristic that with regard to natural conditions assumes various sizes (e.g. vertical climatic zones, relief or soil classes).

Soil quality is one of the most important factors conditioning potential options for deriving high income from agricultural activity [2;3]. Therefore, it is necessary to monitor changes in the use of land $[4 ; 5]$. Throughout the area of Poland uniform classification of soil was applied taking into account soil morphology and its physical properties. The study contains elaborate descriptive and cartographic material such as classification maps in the scale equivalent to cadastral maps [6]. Agricultural quality of soil is determined by soil classes, and suitability of land for the cultivation of specific crops or groups of crops - soil and agricultural complexes. Detailed studies carried out by Witek and Górski [7] with regard to planning of crops of 4 cereals and potatoes in Poland for respective classes of cropland and grassland, quantified the production values of production classes according to a 100-point scale. The classification was used in developing a method for the appraisal of land for land consolidation and exchange works $[1 ; 8]$. The classification according to uses can be applied in economic practice better by being expressed as a single number in the form of a productivity ratio rather than a soil quality index. The quantified potential quality score of respective classes of cropland is the productive value of soil classes. The type of use and soil quality class both affect the value of land in the appraisal process related to land consolidation and exchange works [9; 10]. It should be noted that the prepared ratios of usefulness of cropland and grassland are used in the algorithm for identifying groups of features for the hierarchization of land consolidation works in rural areas [11], which at a later stage results in the hierarchization of land consolidation works in rural areas as mentioned by [12-15]. Apart from their economic effects [16], land consolidation works are a tool for ordering the agricultural production space, but they also provide a possibility of alternative management of disadvantaged areas of no agricultural use [17-19].

This condition underlies the purpose of this work; that is, calculating the ratio of usability of cropland and grassland for identifying villages similar in that respect. The studies were carried out in 17 villages in the Księżpol commune in Lubelskie voivodship (Fig. 1). 


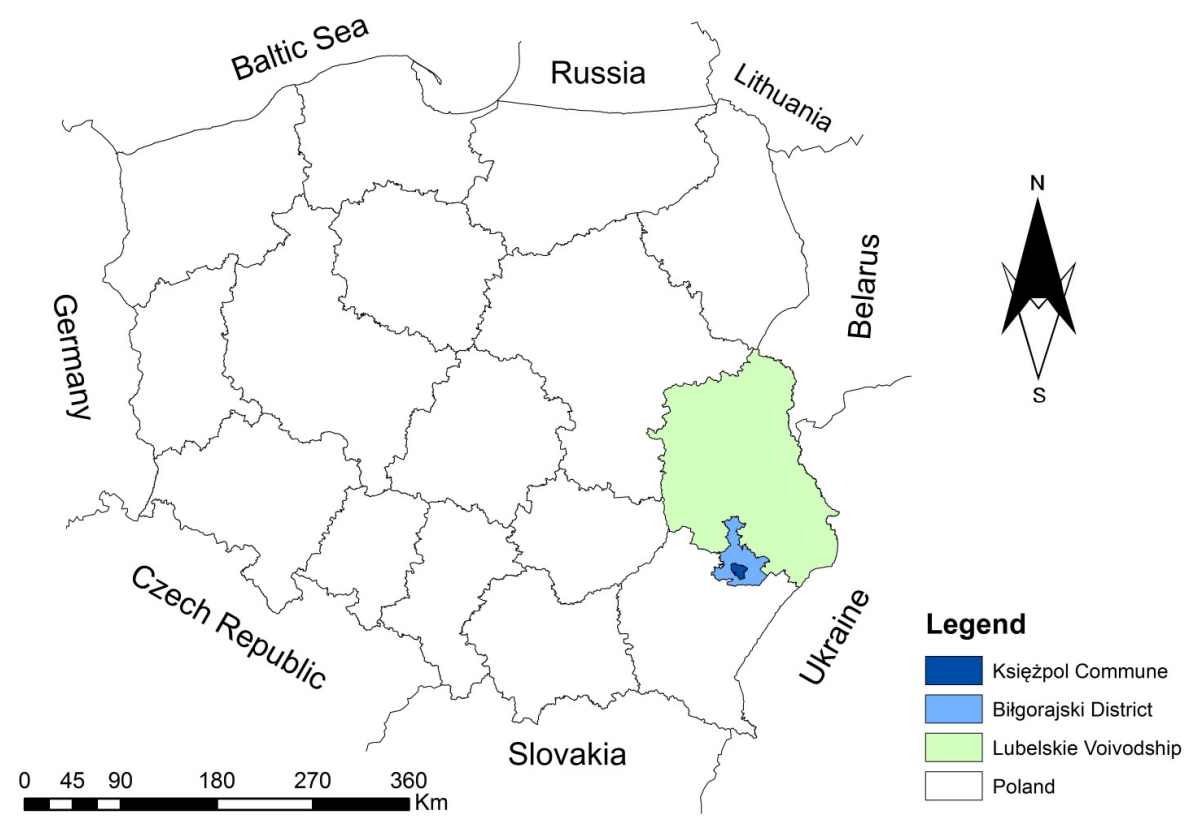

Fig. 1. Map of location of analyzed commune

Data relating to surface of respective classes of soil were retrieved from the land and buildings register and the calculation of the ratio was based on scores assigned on a 100-point working scale.

\section{Materials and methods}

The scores assigned to classes of soil applicable to cropland and grassland in Poland (Tab. 1) were adopted directly, without any additional criteria, which are used for calculating the soil quality index.

\section{Scores assigned to soil classes for cropland and grassland}

Table 1

\begin{tabular}{|c|c|c|}
\hline Soil class & Cropland & Grassland \\
\hline I & 100 & 90 \\
\hline II & 92 & 80 \\
\hline IIIa & 83 & \multirow{2}{*}{65} \\
\hline IIIb & 70 & \\
\hline IVa & 57 & \multirow{2}{*}{45} \\
\hline IVb & 40 & 38 \\
\hline V & 30 & 15 \\
\hline VI & 18 & \\
\hline
\end{tabular}

The productivity ratio ( $w p W-$ in points) of cropland and grassland for respective villages was calculated from the formula:

$$
W_{w p}=\frac{\sum_{1}^{n}\left(x_{n} \cdot W_{p}\right)}{P},
$$

where the scores assigned to classes of soil applicable to cropland and grassland in Poland (Table 1):

$x_{n}$ - surface covered by respective soil classes in cropland or grassland;

$P$ - total surface covered by soil classes in cropland or grassland.

The productivity ratio is calculated separately for cropland $\left(W_{w g}\right)$ and grassland $\left(W_{w u}\right)$, as they cannot be treated cumulatively due to different scores assigned to soil classes in connection with their 
productivity. The production space of the commune was divided with regard to the soil productivity ratio according to scores indicated in Table 1. The adopted criterion was used for the purposes of two independent divisions including cropland and grassland with 4 groups of villages identified in cropland, and 7 groups in grassland.

Table 2

Grouping of villages with regard to soil productivity ratio

\begin{tabular}{|c|c|c|c|}
\hline \multicolumn{2}{|c|}{ For cropland } & \multicolumn{2}{c|}{ For grassland } \\
\hline $\begin{array}{c}\text { Group of } \\
\text { villages }\end{array}$ & Range of the ratio & $\begin{array}{c}\text { Group of } \\
\text { villages }\end{array}$ & Range of the ratio \\
\hline \multirow{2}{*}{1} & \multirow{2}{*}{ below 15.00} & 1 & $0.00-2.00$ \\
\cline { 3 - 4 } & \multirow{2}{*}{2} & 2 & $2.01-4.00$ \\
\hline \multirow{2}{*}{3} & \multirow{2}{*}{$30.01-30.00$} & 3 & $4.01-6.00$ \\
\cline { 3 - 4 } & & 4 & $6.01-8.00$ \\
\hline 4 & above 45.0 & 5 & $8.01-10.00$ \\
\cline { 3 - 4 } & & 7 & $10.01-12.00$ \\
\hline
\end{tabular}

Source: own study based on data from the register of land and buildings.

The values of productivity ratios of cropland and grassland calculated for respective villages are represented in Table 3 incrementally. At the same time, their percentage share in the total area of the village is indicated. Soil productivity ratio both for cropland and grassland is distributed in a very differentiated way taking into account the number of villages per group and their spatial distribution. And thus, the group of villages with the ratio (above 45.00), that is, with the best productivity in the analyzed area, comprises two villages (Płusy and Korchów). The range 30.01-45.00 also comprised two villages (Zawadka and Przymiarki). Group II where the ratio of productivity ranges from 15.01 to 30.00, includes 6 villages whereas 7 villages were classified as group I with a ratio lower than 15. 00.

Another ratio calculated separately is the productivity of grassland. According to Table 3 the ratio for grassland makes reference to the ratio for cropland only in part. In group VII with the highest ratio for grassland (12.01-14.00) there is only one village (Markowicze), which was characterized by a low ratio for cropland. In group VI, where the ratio was 10.01-12.0, three villages were included (Płusy, Rogale, Zanie), with a relatively high ratio for cropland. Group V, likewise group III, consisted of 5 villages. Only 2 villages (Księżpol and Zawadka) are classified as group IV with the ratio ranging from 6.01 to 8.00. The presence of Lipowiec Mały in group II testifies to quite poor soil quality in that village, since this village was also included in the lowest group for the ratio for cropland.

Table 3

Value of productivity ratios of soil classes for cropland and grassland

\begin{tabular}{|c|c|c|c|c|c|c|c|c|}
\hline No. & Village & $\begin{array}{c}\text { \% of } \\
\text { cropland in } \\
\text { total village } \\
\text { area }\end{array}$ & $\begin{array}{c}\text { Score ratio } \\
\boldsymbol{W}_{w g}\end{array}$ & No. & Village & $\begin{array}{c}\text { \% of } \\
\text { grassland in } \\
\text { total village } \\
\text { area }\end{array}$ & $\begin{array}{c}\text { Score } \\
\text { ratio } \boldsymbol{W}_{w g}\end{array}$ \\
\hline \multicolumn{6}{|c|}{ Group I villages (less than 15.00$)$} & \multicolumn{5}{|c|}{ Group II villages (2.01-4.00) } \\
\hline 1 & $\begin{array}{c}\text { Lipowiec } \\
\text { Duży }\end{array}$ & 12.7 & 3.44 & 1 & \multicolumn{2}{|c|}{$\begin{array}{c}\text { Lipowiec } \\
\text { Mały }\end{array}$} & 11.6 & 3.21 \\
\hline 2 & $\begin{array}{c}\text { Lipowiec } \\
\text { Mały }\end{array}$ & 15.6 & 3.49 & \multicolumn{5}{|c|}{ Group III villages (4.01-6.00) } \\
\hline 3 & Króle & 12.9 & 4.08 & 2 & Korchów & 9.5 & 4.32 \\
\hline 4 & $\begin{array}{c}\text { Majdan } \\
\text { Nowy }\end{array}$ & 26.9 & 7.37 & 3 & $\begin{array}{c}\text { Korchów } \\
\text { Lęgi }\end{array}$ & 17.3 & 4.54 \\
\hline 5 & Zynie & 37.9 & 11.51 & 4 & $\begin{array}{c}\text { Lipowiec } \\
\text { Duży }\end{array}$ & 13.4 & 5.13 \\
\hline
\end{tabular}




\begin{tabular}{|c|c|c|c|c|c|c|c|}
\hline 6 & Majdan Stary & 44.7 & 12.00 & 5 & Króle & 16.3 & 5.31 \\
\hline 7 & Markowicze & 47.9 & 14.95 & 6 & $\begin{array}{c}\text { Majdan } \\
\text { Nowy }\end{array}$ & 17.4 & 5.51 \\
\hline
\end{tabular}

\begin{tabular}{|c|c|c|c|c|c|c|c|}
\hline \multicolumn{8}{|c|}{ Table 3 (continued) } \\
\hline No. & Village & $\begin{array}{c}\% \text { of } \\
\text { cropland in } \\
\text { total village } \\
\text { area }\end{array}$ & $\begin{array}{c}\text { Score ratio } \\
W_{w g}\end{array}$ & No. & Village & $\begin{array}{c}\% \text { of } \\
\text { grassland in } \\
\text { total village } \\
\text { area }\end{array}$ & $\begin{array}{c}\text { Score } \\
\text { ratio } W_{w g}\end{array}$ \\
\hline 4 & $\begin{array}{l}\text { Majdan } \\
\text { Nowy }\end{array}$ & 26.9 & 7.37 & 3 & $\begin{array}{c}\text { Korchów } \\
\text { Łęgi }\end{array}$ & 17.3 & 4.54 \\
\hline 5 & Zynie & 37.9 & 11.51 & 4 & $\begin{array}{c}\text { Lipowiec } \\
\text { Duży }\end{array}$ & 13.4 & 5.13 \\
\hline 6 & $\begin{array}{l}\text { Majdan } \\
\text { Stary }\end{array}$ & 44.7 & 12.00 & 5 & Króle & 16.3 & 5.31 \\
\hline 7 & Markowicze & 47.9 & 14.95 & 6 & $\begin{array}{l}\text { Majdan } \\
\text { Nowy }\end{array}$ & 17.4 & 5.51 \\
\hline \multicolumn{4}{|c|}{ Group II villages (15.01-30.00) } & \multicolumn{4}{|c|}{ Group IV villages (6.01-8.00) } \\
\hline 8 & Zanie & 53.9 & 15.56 & 7 & Księżpol & 17.8 & 7.35 \\
\hline 9 & Rogale & 57.4 & 16.08 & 8 & Zawadka & 17.0 & 7.42 \\
\hline 10 & $\begin{array}{c}\text { Korchów } \\
\text { Łęgi }\end{array}$ & 70.9 & 21.42 & \multicolumn{4}{|c|}{ V grupa wsi (8.01-10.0) } \\
\hline 11 & Borki & 64.5 & 28.32 & 9 & Rakówka & 20.4 & 8.03 \\
\hline 12 & Rakówka & 61.0 & 29.31 & 10 & Zynie & 22.2 & 8.21 \\
\hline 13 & Księżpol & 68.3 & 29.93 & 11 & Przymiarki & 18.8 & 8.85 \\
\hline \multicolumn{4}{|c|}{ Group III villages (30.01-45.0) } & 12 & Borki & 26.4 & 9.07 \\
\hline 14 & Zawadka & 70.8 & 33.59 & 13 & Majdan Stary & 27.0 & 9.88 \\
\hline 15 & Przymiarki & 69.7 & 35.76 & \multicolumn{4}{|c|}{ Group VI villages (10.01-12.0) } \\
\hline \multicolumn{4}{|c|}{ Group IV villages (above 45.0) } & 14 & Płusy & 20.0 & 10.59 \\
\hline \multirow{2}{*}{16} & \multirow{2}{*}{ Płusy } & \multirow{2}{*}{72.0} & \multirow{2}{*}{50.25} & 15 & Rogale & 30.0 & 10.89 \\
\hline & & & & 16 & Zanie & 27.4 & 11.01 \\
\hline \multirow{2}{*}{17} & \multirow{2}{*}{ Korchów } & \multirow{2}{*}{81.6} & \multirow{2}{*}{54.57} & \multicolumn{4}{|c|}{ Group VII villages (12.01-14.00) } \\
\hline & & & & 17 & Markowicze & 33.9 & 12.33 \\
\hline
\end{tabular}

Source: own study based on data from the register of land and buildings.

Information about the quality of land in respective villages can be optionally taken into account in calculating the final synthetic measure and the weight of such information can be significant in that case.

\section{Results and discussion}

Tables 2 and 3 were used to draw Figures 2 and 3, illustrating average variations in spatial distribution of soil classes in the Księżpol commune. With regard to the ratio of productivity of cropland it is noticeable that villages in the Księżpol commune form clusters of similar productivity. Best quality soils occur in the southern part of the commune. On the other hand, the least productive cropland is situated in the north of the commune. According to data given in Table 3, a decrease in the value of the ratio is correlated with the percentage share of cropland in the area of the villages. The less cropland, the lower the ratio. In studies concerning spatial and economic phenomena occurring in rural land, respective villages are grouped into larger typological units with respect to similarity of their features [12]. The classification was used in developing a method for the appraisal of land for land consolidation and exchange works. Based on the studies concerning the ratio of productivity of cropland in the process of land consolidation and exchange, the classification according to uses can be better applied in economic practice by being expressed as a single number in the form of productivity ratio rather than the soil quality index. 
With regard to the ratio of productivity of grassland, it is noticeable that villages in the Księżpol commune form clusters of similar productivity, but these clusters are more differentiated than in case of cropland. The highest productivity of grassland was recorded in Markowicze, which can be due to the presence of quite a large area covered by meadows near the Tanew river flowing through the analyzed village. The location of the village by the river decreases the share of cropland, while the share of meadows is increased. Along with the increasing absolute value of soil-water potential the value of crops increases [20].

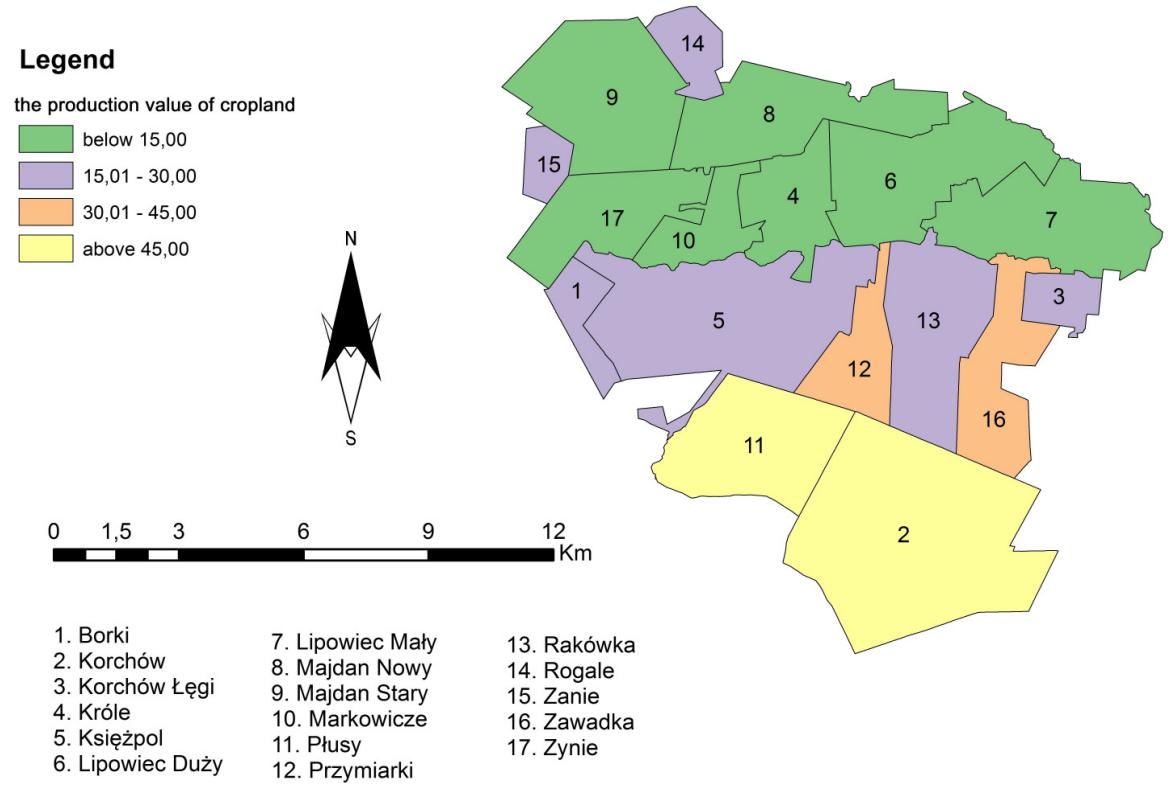

Fig. 2. Spatial division of Księżpol commune with regard to productivity of cropland

A similar situation occurs in 3 villages from group VII (Płusy, Rogale, Zanie), where the water regime is favourable for the development of meadows and pastures. Similar to cropland, the ratio of productivity of grassland is correlated with their share in the total area of the village. The more grassland, the higher the ratio of productivity.

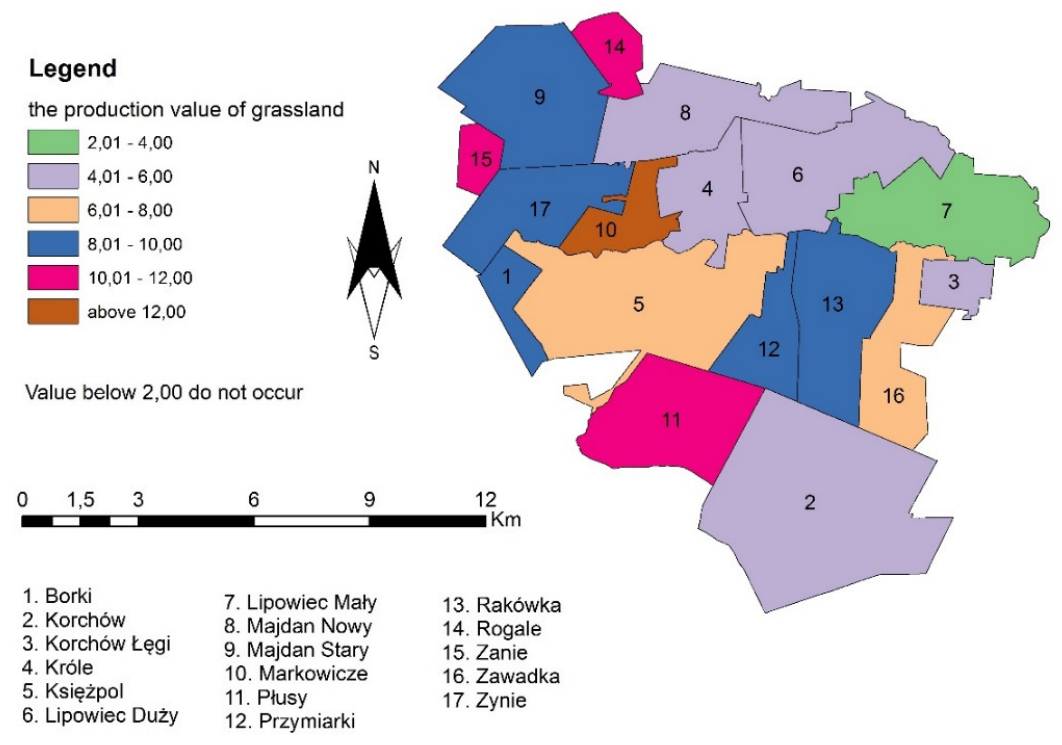

Fig. 3. Spatial division of Księżpol commune with regard to productivity of grassland

\section{Conclusions}


1. The application of a single number as the value of productivity for cropland and grassland and grouping them in respective ranges provide a possibility of grouping respective villages into larger typological units with regard to the similarity of features. Villages form characteristic areas are making reference to terrain relief and water regime within the analyzed area.

2. The division of agricultural production space according to the value of productivity ratios provides significant information for making decisions related to land management. Productivity of cropland and grassland expressed in numbers is important information for the planning and programming of land consolidation and exchange works.

3. When the calculated ratios and other characteristics describing the spatial structure of the analyzed area are applied, such an area can be delimited. The calculated ratios can also be used for economic, spatial or land development planning purposes.

\section{References}

[1] Noga K.. Sposób szacunku gruntów w terenach górskich (Methods of appraisal of land in mountainous areas). Scientific Booklets of the University of Agriculture in Wrocław. ser. Geodesy and Rural Land Management. 187, 1989, pp. 197-206, (In Polish)

[2] Janus J., Taszakowski J. Spatial differentation of the soil quality in Dąbrowski administrative district. Infrastructure and Ecology of Rural Areas. No. 2014/ II (2 (Jun 2014)), pp. 609-622, (In Polish)

[3] Kadlec V., Zizala D., Novotny I., Hermanovska D., Kapicka J., Tippl M. Land Consolidations as an effective instrument in soil conservation. Ekologia (Bratislava), 2014, Vol. 33, No. 2, pp. $188-200$

[4] Noszczyk T., Rutkowska A., Hernik J. Determining Changes in Land Use Structure in Małopolska Using Statistical Methods. Polish Journal of Environmental Studies, 2017, 26(1), pp. 211-220. DOI: $10.15244 /$ pjoes/64913

[5] Noszczyk T. Land use change monitoring as a task of local government administration in Poland. Journal of Ecological Engineering, 2018, 19(1), pp. 170-176. DOI: 10.12911/22998993/7940

[6] Leń P. Breakdown of county agricultural space Brzozowski in terms of production value of cropland and grassland. Infrastructure and Ecology of Rural Areas. vol. 12/2010, 2010, pp. 37-44.

[7] Witek T., Górski T. Przyrodnicza Bonitacja Rolniczej Przestrzeni Produkcyjnej w Polsce (Natural classification of soil quality in the agricultural production space in Poland), 1977, Wydawnictwa Geologiczne, Warszawa, (In Polish)

[8] Noga K. Metodyka programowania i realizacji prac scalenia i wymiany gruntów w ujęciu kompleksowym (Comprehensive methodology of programming and performance of land consolidation and exchange works). School of land studies. Kraków, 2001, pp. 30, (In Polish)

[9] Dudzińska M. Czynniki determinujące wartość rynkową gruntu rolnego i wartość gruntu w postępowaniu scaleniowym. (Factors determining the market value of agricultural land and the value of land in consolidation proceedings). Acta Scientiarum Polonorum. Vol. 9 (4), 2010, pp. 19-28, (In Polish)

[10] Sobolewska-Mikulska K. Procedury prawno-geodezyjne w gospodarce gruntami na obszarach rolnych (Legal and land surveying procedures in the management of rural land). Warszawa: Oficyna Wydawnicza Politechniki Warszawskiej, 2015. pp. 23, (In Polish)

[11] Len P. An algorithm for selecting groups of factors for prioritization of land consolidation in rural areas. Computers and Electronics in Agriculture, 144, 2018, pp. 216-221. DOI: 10.1016/j.compag.2017.12.014

[12] Len P. Methodology of hierarization of the work of land consolidation and land exchange. The World Multidisciplinary Earth Sciences Symposium (WMESS 2017). IOP Conf. Series: Earth and Environmental Science 95 (2017) 032010, September 11-15, 2017, Prague, DOI :10.1088/1755$1315 / 95 / 3 / 032010$

[13] Len P. The use of statistical methods in creation of the urgency ranking of the land consolidation and land exchange works. "Environmental Engineering" 10th International Conference Vilnius Gediminas Technical University, April 27-28, 2017, Lithuania, eISSN 2029-7092 / eISBN 978609-476-044-0, DOI: https://doi.org/10.3846/ enviro.2017.212 
[14]Len P., Mika M. Determination of the urgency of undertaking land consolidation works in the villages of the Sławno municipality. Journal of Ecological Engineering. Volume 17, Issue 4, Sept. 2016, pp. 163-169 DOI: 10.12911/22998993/64827.

[15] Leń P., Noga K. Prioritization of Land Consolidation Interventions in the Villages of Central Poland. Journal of Ecological Engineering, Volume 19, Issue 2, March 2018, pp. 248-256.

[16]Leń P., Król Z. Analysis of economic and environmental effects of land consolidation on the example of Hucisko village. Journal of Ecological Engineering. Volume 17, Issue 5, Nov. 2016, pp. 232-239. DOI: 10.12911/22998993/65090.

[17] Wójcik-Leń J., Sobolewska-Mikulska K., Specific features of development of selected agricultural problematic areas in the land consolidation process. Journal of Water and Land Development, 2017, No. 34, pp. 249-258, DOI: 10.1515/jwld-2017-0060.

[18] Wójcik-Leń J., Sobolewska-Mikulska K. Issues related to marginal lands with reference to selected agricultural problematic areas. Journal of Water and Land Development, 2017, No. 35, pp. 265-273, DOI: 10.1515/jwld-2017-0093.

[19] Wójcik-Leń J., Stręk Ż., 2017. Proposal for land consolidation project solutions for selected problem areas. World Multidisciplinary Earth Sciences Symposium (WMESS 2017). Earth and Environmental Science 95 (2017) 032016, September 11-15, 2017, Prague, DOI :10.1088/17551315/95/3/032016

[20] Szajda J., Łabędzki L. Szacowanie plonów rzeczywistych z użytków zielonych na podstawie plonów maksymalnych i potencjału wody w glebie (Appraisal of the actual yield of grassland based on maximum yield and water-soil potential). Water-Environment-Rural Areas. 2016 (I-III). T. 16. Z. 1 (53). pp. 93-114, (In Polish) 